\title{
EL SINIESTRO ESTRABISMO. HISTORIOGRAFÍA Y NACIÓN EN LA ESPAÑA CONTEMPORÁNEA
}

por

\author{
JuAN MARÍa SÁNCHez-PRIETO
}

Universidad Pública de Navarra.

RESUMEN: La identidad se sustenta en la idea que una sociedad se bace de sí misma, y en esa imagen construida la memoria de la bistoria juega un papel esencial. El papel de la bistoriografía es inseparable de la comprensión de cualquier grupo, comunidad o nación como comunidad de relato y urdimbre de sentido. Desde esa perspectiva se puede plantear hasta qué punto el desarrollo de los nacionalismos en España durante los siglos $X I X$ y XX presenta raices realmente distintas o son, por el contrario, mayores los aspectos comunes que subyacen en la construcción del discurso de la identidad, y en la misma acción del olvido a lo largo del tiempo. El análisis de las historiografías catalana y vasca, al filo de la española, muestra cómo las fuentes intelectuales que alimentan la conciencia nacional y que fundamentan el propio discurso bistórico sobre la nación a lo largo del tiempo, no son específicas, sino que participan de la atmósfera europea, y son a fin de cuentas muchas veces las mismas. Más allá de las imágenes fabricadas y del antagonismo resultante en el cruce de miradas, es obvio que identidades desenvueltas dentro de la misma estratosfera cultural están más próximas de compartir proyectos comunes.

Palabras clave: Historia de la historiografía. Memoria. Política. Identidad. Nacionalismos. España. Cataluña. País Vasco.

ABSTRACT: Identity is sustained by the self-perception of society, and in this constructed image, bistorical memory plays an essential role. The role of historiography is inseparable from an understanding of a group, community or nation as being beld together by narrative and a web of meaning. From this perspective, one can investigate the extent to which the development of nationalisms in Spain in the nineteenth and twentieth centuries presents genuinely different roots, or whether - conversely - their similarities are greater than their differences, in the construction of identity discourse and in forms of historical forgetting. The analysis of Catalan and Basque bistoriography, alongside Spanish forms,

Hispania, LXV/1, núm. 219 (2005) 281-306 
shows bow the intellectual sources that feed national consciousness, and that underlie the bistorical discourse of nationbood itself over time, are not specific but rather breathe in a larger European atmosphere, and are frequently the same. Beyond the fabricated selfimages and the consequent mutual antagonism, it is quite clear that identities developed in the same cultural stratosphere are in fact engaged in a common project.

KEY WORDS: Historiography. Politics. Identity Nationalisms. Spain. Catalonia. Basque Country.

La historia de la historiografía se ha convertido en una cinta registradora de los mil y un intereses dispersos que ocupan de manera diversa a los historiadores. Sometidos a la luz de la crítica, asegura asimismo la actividad de los teóricos de la disciplina, que valoran su adecuación a las principales tendencias y modas del momento ${ }^{1}$. Las controversias suscitadas por determinadas cuestiones atraen las miradas y garantizan de forma periódica el espectáculo de la discusión académica, salteada de otras motivaciones intelectuales o ideológicas. Los nacionalismos en España constituyen un tema recurrente de conversación científica y política, cansino e inevitable a la vez, pues son los propios historiadores quienes, dueños de la perspectiva histórica, lo han apuntado como el problema fundamental de nuestro tiempo, y quienes, históricamente, más han contribuido también a armarlo. El propósito de estas páginas no es abordar la evolución del debate historiográfico reciente sobre la nación o los nacionalismos, sino atender más bien a la propia dimensión de la historiografía como forja de la nación y de las representaciones colectivas en la época contemporánea. Nacionalista o no, la historia es inseparable de la cuestión de la identidad, alimenta la memoria colectiva y desempeña un papel fundamental en la formación de las actitudes políticas y en la formulación del proyecto de convivencia ${ }^{2}$.

De un modo sintético se pretenden explorar los principales momentos del entrecruzamiento de historiografía y nación en la España contemporánea, con especial referencia al marco general español, aunque no faltarán menciones a los casos catalán y vasco, y al escenario mayor europeo. En el empeño, late una pregunta, o si se quiere una hipótesis mal formulada: hasta qué punto esos casos presentan raíces realmente distintas, o son, por el contrario, mayores los

1 Pasamar, G. e I. Peiró: Diccionario de historiadores españoles contemporáneos: 1840-1980, Madrid, Akal, 2002. HERNÁNDEZ SANDOICA, E: «La historia contemporánea en España: Tendencias recientes», en Hispania (Madrid), 198 (1998), pp. 65-95.

2 Ricoeur, P.: La memoria, la historia, el olvido, Madrid, Trotta, 2003. OlÁBARRI, I: «La resurrección de Mnemósine: historia, memoria e identidad», en I. OLÁBARRI y F.J. CASPISTEGUI (dirs.) La "nueva" historia cultural: la influencia del posestructuralismo y el auge de la interdisciplinariedad, Madrid, Editorial Complutense, 1996, pp. 145-173. CuESTA BuSTILlO, J.: Memoria e historia Madrid, Marcial Pons, 1998 (núm. 32 de la revista Ayer). SÁNCHEZ-PRIETO, J.M.: «L'approche dramatique de l'histoire», en Ch. Amalvi (dir.): Une passion de l'bistoire. Histoire(s), mémoire(s) et Europe. Hommage à Charles-Olivier Carbonell, Toulouse, Privat, 2002, pp. 349-359. 
aspectos comunes que subyacen en la construcción del discurso de la identidad, y en la misma acción del olvido a lo largo del tiempo. Cuestión diferente, aunque secundaria a estos efectos, es el nivel de proximidad de las distintas representaciones históricas respecto de la realidad o problemática nacional, por mucho que, en determinados ámbitos y momentos, puedan incidir en la imagen que la propia comunidad tenga de sí misma, y a la postre en las singularidades de una conciencia histórica o de una cultura política.

La exposición descansará en los cinco puntos siguientes, como principales jalones de un proceso: el alumbramiento de la nación, las historias nacionales, el mito de las dos Españas, la deformación de la conciencia histórica y, por último, la reinvención de la nación.

\section{EL ALUMBRAMIENTO DE LA NACIÓN}

El poder político hizo de la España de Felipe V una España de nueva planta. Los planes de centralización borbónica, haciendo efectivos los propósitos frustrados del Conde Duque de Olivares el siglo anterior, alteraron el cuerpo político de los viejos países forales (Cataluña, Aragón, Valencia, Mallorca) a excepción del País Vasco que luchó al lado de Felipe $V$ en la guerra de sucesión: no hubo nueva planta para las provincias del Norte ${ }^{3}$.

La fundación de las Academias en el siglo XVIII, símbolo del espíritu de las luces, significó una intervención del Estado en la cultura, puesta al servicio de los grandes ejes de la política ilustrada: la afirmación de la nación y la racionalización administrativa. La historiografía no queda al margen. La Real Academia de la Historia, fundada en 1738 siguiendo el modelo francés, es un claro ejemplo de racionalismo, erudición y crítica dirigidos a ilustrar la historia de España, "purificándola de fábulas y errores», mediante el establecimiento riguroso de los hechos y la verificación de los datos ${ }^{4}$. Cataluña y el País Vasco no se sitúan fuera del movimiento ilustrado. Muestra de ello son la Real Academia de Buenas Letras (1729) de Barcelona, temprana escuela del método filológico y crítico, o la Sociedad Bascongada de Amigos del País (1764), que se propuso desde sus inicios la elaboración de una «Historia Nacional de las tres Provincias»s.

3 JOVER, J.M.: La civilización española a mediados del XIX, Madrid, Espasa Calpe, 1991 (a), p. 118. GARCí́ CÁRCEL, R.: Felipe V y los españoles, Barcelona, Plaza \& Janés, 2002. Fernández ALBALADEJO, P. (ed.): Los borbones. Dinastía y memoria de nación en la España del siglo XVIII, Madrid, Marcial Pons \& Casa de Velázquez, 2002. ONAINDIA, M.: La construcción de la nación española: republicanismo y nacionalismo en la llustración, Barcelona, Ediciones B, 2002.

${ }_{4}$ Rumeu De ARmas, A.: «Real Academia de la Historia», en Las Reales Academias del Instituto de España, Madrid, Alianza, 1992, pp. 105-169.

5 OláBARRI, I.: «Proyectos historiográficos de la Real Sociedad Bascongada de los Amigos del País", en I Seminario de Historia de la Real Sociedad Bascongada de Amigos del País, San Sebastián, Diputación de Guipúzcoa, 1986, pp. 459-470. 
La historiografía del XVIII, más allá de la fecundidad de autores como Mayans o Flórez, introdujo la cuestión del carácter nacional español. La polémica levantada por el célebre artículo de Masson de Morviliers en la Enciclopedia «¿Qué se debe a España? En dos siglos, en cuatro, en diez, ¿qué es lo que ha hecho por Europa?» (1782) establece el prólogo del sentimiento nacionalista en la historiografía española ${ }^{6}$. Masdeu, Capmany y Forner encabezan la reacción patriótica. La Oración apologética por España (1786) de Forner fue escrita por encargo de Floridablanca para rebatir a Masson?. Antes Masdeu, en su Historia crítica de España y de la cultura española (1783-1805), había reaccionado contra la "prevención universal», escribía, de referirse a España como «nación por carácter perezosa, ociosa y negligente», de hombres descuidados y sin genio. Quedaba planteada la idea del carácter nacional que acompañará a historiografía española a lo largo de los siglos XIX y XX $\mathrm{XX}^{8}$. Por su parte, el catalán Capmany rindió culto en ese momento a la lengua castellana (su Teatro histórico-critico de la elocuencia española, 1786) y reaparecerá en 1808 como punta de lanza del nacionalismo español (su Centinela contra franceses, grito a favor de la patria y el espíritu nacional). De este modo, la crítica ilustrada europea vertida contra España había puesto las bases, al calor de la polémica, de la exaltación de la nación.

El caso vasco responde al mismo patrón. La ofensiva de Godoy ${ }^{9}$ contra los fueros a finales del XVIII, retomando la empresa uniformadora, comprometió a la Real Academia de la Historia en la crítica lanzada contra los fundamentos históricos de las instituciones vascas, lo que desencadenó la reacción de la élite intelectual vascongada, el grupo de Astarloa, cuya producción acerca de la historia y la lengua vascas, enlazando con los mitos de los siglos anteriores, será reeditada de nuevo a finales del XIX, después de la abolición de los fueros de 1876, e influirá de modo singular en los postulados, lingüísticos sobre todo, de Sabino Arana ${ }^{10}$.

La Guerra de la Independencia supuso el descubrimiento romántico de la nación española, como sentimiento antes que idea. Los españoles en 1808 se descubren a sí mismos compartiendo unos sentimientos y valores comunes. No se puede obviar la proyección de la guerra en la generalización del sentimiento de nación y el desarrollo de una conciencia colectiva entre los españoles. Después, las Cortes de Cádiz desarrollarán la idea revolucionaria de nación, de matriz francesa ${ }^{11}$.

\footnotetext{
${ }^{6}$ MORENO ALONSO, M.: «El sentimiento nacionalista en la historiografía española del siglo XIX», en Nation et nationalités en Espagne. XIXe-XXe siècles, París, Fondation Polignac, 1985, pp. 63-122.

7 JimÉnez SAlas, M.: Vida y obras de D. Juan Pablo Forner, Madrid, Instituto Nicolás Antonio, 1944.

8 CATALÁN, D.: «España en su historiografía: de objeto a sujeto de la historia», introducción a MENÉNDEZ PidAL, R. Los españoles en la historia, Madrid, Espasa Calpe, 1982, pp. 54-55.

9 LA PARRA, E.: Manuel Godoy. La aventura del poder, Barcelona, Tusquets, 2002.

10 JUARISTI, J.: «Las fuentes ocultas del romanticismo vasco», en Cuadernos de Alzate (Madrid), 7 (1987), pp. 86-105.

11 GUERRA, F.X.: Modernidad e independencias, Madrid, Mafre, 1992; "De la política antigua a la política moderna. La revolución de la soberanía», en F.X. GUERRA, A. LEMPÉRIÈRE y otros, Los 
Aunque la guerra suponga una explosión de nacionalismo español, no obra, con todo —es preciso subrayarlo_-, la unidad nacional. Frente al sentimiento unificador, la idea revolucionaria de nación fuerza — como había sucedido con la Revolución Francesa- la división entre buenos y malos españoles, obstáculo que habrá que salvar para alcanzar una auténtica conciencia de unidad nacional. La Historia del levantamiento, guerra y revolución de España (1835) de Toreno identifica la nación con la epopeya del liberalismo. Al igual que sucede en Francia, pasará tiempo antes de que pueda elaborarse una visión de la revolución aceptable por todos, incluso por quienes participan de las mismas fuentes ideológicas (la consagración del nombre de guerra de la independencia, alrededor de mediados de siglo, es un hecho indicativo al respecto ${ }^{12}$ ).

En este contexto, la visión de España alimentada por los afrancesados, alineados en la guerra a favor de Bonaparte por razones, más intelectuales que pasionales, de conveniencia nacional, puede considerarse como la primera idea europea de España no nacionalista (a diferencia de los patriotas), aunque no cuente en esos momentos con grandes expresiones historiográficas (si se exceptúa la obra de Llorente), pero sí más adelante ${ }^{13}$.

No faltaron intentos historiográficos, motivados principalmente por cuestiones de estrategia política, no tanto de erudición, de fundamentar la obra política española dentro de la tradición pactista. Martínez Marina, el autor de una Teoría de las Cortes (1813) sustentada en el respeto de la supuesta constitución histórica del Reino, será considerado más tarde por Menéndez y Pelayo como el fundador de la historia interna de la península. Jovellanos también insistió Sobre la necesidad de unir al estudio de la legislación el de nuestra bistoria y antigüedades (título de su discurso en la Academia de la Historia), y a él se debería, según Claudio Sánchez Albornoz, la formulación del concepto de constitución interna no sólo en España, sino con anterioridad a Savigny ${ }^{14}$. Estas posiciones, aunque no triunfen durante la guerra de la independencia, se proyectan políticamente en los planteamientos historicistas del liberalismo doctrinario de 1830 , y van a explicar la vigencia del pactismo en el horizonte vasco del primer tercio de siglo.

Dentro de la lógica de las formulaciones de Jovellanos o Martínez Marina hay que situar igualmente a Capmany, muestra de la participación catalana en la discusión del primer proyecto nacional español, al abogar por la asunción de

espacios públicos en Iberoamérica. Ambigüedades y problemas. Siglos XVIII-XIX, México, FCE, 1998, pp. 109-139.

12 Álvarez Junco, J.: Mater dolorosa. La idea de España en el siglo XIX, Madrid, Taurus, 2001, p. 128.

${ }^{13}$ LÓPEZ TABAR, J.: Los famosos traidores. Los afrancesados durante la crisis del Antiguo Régimen (1808-1833), Madrid, Biblioteca Nueva, 2001.

14 SánChez Albornoz, C.: Ensayos sobre bistoria de España, Madrid, Siglo XXI, 1973, p. 132. ÁlvAREZ-VALDÉs, M.: Jovellanos: enigmas y certezas, Gijón: Fundación Alvargonzález, 2002. CASO, J.M.: Jovellanos, Barcelona: Ariel, 1998. FernÁNDEZ ÁlvareZ, M.: Jovellanos: biografía, Madrid, Espasa Calpe, 1988. 
las tradiciones políticas de los antiguos reinos peninsulares en el nuevo marco institucional liberal ${ }^{15}$, sin cejar, por otro lado, de animar a los «buenos españoles» a defender la Nación y a constituir "cátedras de patriotismo» ${ }^{16}$.

En definitiva, en el tránsito del siglo XVIII al XIX se asiste al alumbramiento de la nación, pero no se puede hablar todavía de una conciencia nacional compartida. En la tarea de formación de esa conciencia jugarán un papel primordial, en las décadas centrales del siglo, las historias nacionales.

\section{LAS HISTORIAS NACIONALES}

El desarrollo de la historia nacional va unido al proceso de construcción del Estado-nación europeo a lo largo del XIX, siglo de la historia y de las nacionalidades al tiempo. En el caso español, se pueden acotar tres momentos de alcance distinto tanto en el plano político como historiográfico: la época doctrinaria, el sexenio democrático-republicano y la restauración canovista.

\section{La época doctrinaria}

La época doctrinaria es el momento de esplendor de las historias nacionales como resultado del maridaje entre historia y política - especialmente fecundo en materia de identidad-operado en Francia en 1830. A impulsos de Guizot $^{17}$, el nuevo significado de la nación como realidad histórico natural (recogiendo los aportes del historicismo inglés y del romanticismo alemán) frente al concepto jacobino de pueblo (que introducía inestabilidad en las instituciones políticas e impedía el asentamiento del Estado) conlleva en Francia un desarrollo historiográfico ${ }^{18}$ que inspirará particularmente a la élite liberal española, en contacto directo en el exilio con las fuentes francesas durante la última década de Fernando VII.

La voluntad de proceder a una síntesis ideológica de tiempos, mediante la consagración de un nuevo pactismo y la afirmación al tiempo del principio de

15 ARBós, X.: La idea de nació en el primer constitucionalisme espanyol, Barcelona, Curial Edicions Catalanes, 1986. GraU, R.: Antoni de Capmany i la renovació de l'bistoricisme polític catalá, Barcelona, Ajuntament de Barcelona, 1994.

${ }^{16}$ CAPMANY, A.: Carta de un buen patriota que reside disimulado en Sevilla escrita a un buen amigo suyo domiciliado boy en Cádiz, Cádiz, 1811, p. 2. Citado por MORENO Alonso, 1985, p. 70.

17 Rosanvallon, P.: Le moment Guizot, París, Gallimard, 1985. Broglie, G.: Guizot, París, Perrin, 2002. Legrand, R.: Guizot et son temps: propos et portraits, Paillart, Abbeville, 2002. VALENSINE, M. (ed.): François Guizot et la culture politique de son temps, París, Gallimard, Seuil, 1991. SPITZER, A.B.: The French Generation of 1820, Princeton, Princeton University Press, 1987.

${ }^{18}$ Crossley, C.: French bistorians and romanticism: Thierry, Guizot, the Saint-Simonians, Quinet, Michelet, Londres, Routledge, 1993. LETERRIER, S-A.: Le XIXè siècle bistorien: anthologie raisonnée, París, Belin, 1997.

Hispania, LXV/1, núm. 219 (2005) 281-306 
nacionalización y centralización, necesitaba un apoyo en la historia general. Era una exigencia que no podía aguardar. La traducción y adaptación de la Historia de España del inglés Dunham (en 1844-46), por Alcalá Galiano, Donoso Cortés y Martínez de la Rosa (este último incorporando un discurso sobre la historia de la Nación española), convertía ese texto en la historia oficiosa del nuevo régimen de los moderados ${ }^{19}$, que impulsará de inmediato — siguiendo las pautas francesas- el proceso de institucionalización de la historia: reorganización de la Academia de la Historia (1847), Comisión de Monumentos (1844), Escuela Superior de Diplomática (1856), Cuerpo de Archiveros, Bibliotecarios y Anticuarios (1858), Árchivo Histórico Nacional (1866), etc. ${ }^{20}$ La historia puesta al servicio del Estado y la nación.

Pero no es esa una tarea que pueda identificarse de forma exclusiva con los moderados. La necesidad de una historia nacional fue colmada por la Historia de Modesto Lafuente (30 volúmenes entre 1850 y 1867), claro ejemplo de síntesis liberal, como manifiesta su ascendiente progresista y su posterior adscripción a la Unión Liberal ${ }^{21}$. No fue la única historia nacional, aunque sí la de mayor relieve. Antes de la suya (además de la obra de Masdeu y de la continuación de la Historia de Mariana publicada en el siglo XVI) se pueden destacar las de Eugenio Tapia, Gonzalo Morón y Juan Cortada: la primera como exponente de una sensibilidad más propiamente progresista; la segunda, mayormente moderada (y al corriente de la historiografía europea, de la que proporciona una excelente información ${ }^{22}$ ); y la tercera, catalana dentro del espacio común de la nación española. No son simples ejemplos de historiografía romántica y liberal - política, fantasiosa o apasionada - ${ }^{23}$ sino manifestaciones de una historia filosófica, como corriente europea específica, volcada singularmente en la historia de la civilización ${ }^{24}$. Después o en paralelo a la de Lafuente, aún se cuentan, entre otras, las historias de Patxot, Cavanilles, Gebhardt, Dionisio Aldama, Ronchi o Zamora y Caballero ${ }^{25}$.

19 JOVER, 1991a, p. 163, nota 36. Otros ejemplos de Historias de España publicadas en Francia, Inglaterra o Alemania entre 1831 y 1845, en ALVAREZ JUNCO, 2001, pp. 283-284, nota 16.

${ }^{20}$ Peiró, I.: Los guardianes de la bistoria, Zaragoza, Instituto Fernando el Católico, 1995, pp. 37-53.

${ }^{21}$ Pérez Bustamante, C.: Primer centenario de la muerte de Don Modesto Lafuente: discurso leido en la junta solemne conmemorativa, Madrid, 1967. ToBAJAS, M.: Vida y obra de Don Modesto Lafuente, Madrid, Universidad Complutense, 1974.

22 MORAles MOYA, A.: «Historia de la Historiografía española», en ARTOla, M. (dir.): Enciclopedia de Historia de España, Madrid, Alianza, 1993, vol. 7. p. 636.

${ }_{23}$ MORENO ALONSO, M.: Historiografía romántica española. Introducción al estudio de la bistoria en el siglo XIX, Sevilla, Universidad de Sevilla, 1979.

${ }^{24}$ KNIBIEHLER, Y.: Naissance des sciences humaines: Mignet et l'bistoire philosophique au XIXè siècle, París, Flammarion, 1973.

${ }^{25}$ La relación completa de historias generales puede verse en B. SÁNCHEZ ALONSO: Fuentes de la bistoria española e hispanoamericana, Madrid, CSIC, 1952, vol. I, pp. 26-27. Buena parte de los 
Toda historia nacional es nacionalista y la de Lafuente no es una excepción. La fiereza de los orígenes históricos (Sagunto, Numancia); el orgullo de la ascendencia goda (donde se fundamenta el sentimiento de libertad, el espíritu legislativo y el espíritu religioso de los españoles); la exaltación de la Reconquista, de los Reyes Católicos y en especial de Isabel de Castilla; la defensa de los comuneros (representantes de las libertades de Castilla) frente a Carlos V; la radical repulsa de la Inquisición y la negativa a la satanización de Felipe II; el elogio de la Ilustración y la glorificación de la guerra de la independencia; la repulsa, en fin, de Fernando VII y de su tiempo, definen los principales lugares y momentos fuertes de la historia de Lafuente, con un claro protagonista, la nación española, cuyos avatares son presentados en un relato continuado, dotado de sentido, desde los orígenes hasta la frontera de lo contemporáneo, como corresponde a una historia nacional, el libro nacional por excelencia, según ha recalcado Jover, valorando asimismo la importancia de la Historia de Lafuente como instrumento esencial de culturización histórica de las clases medias españolas durante el siglo XIX ${ }^{26}$.

El relato de Lafuente privilegia los períodos donde se progresa hacia la consolidación del Estado a partir del principio monárquico. La Monarquía es considerada como columna vertebral de la nación y pilar fundamental de la identidad española. Monarquía y nación progresan unidas, en consonancia con los postulados de la soberanía compartida del doctrinarismo liberal. El reino visigodo, los visigodos, se convierten así en el primer símbolo de la unidad nacional y en figura misma de la España isabelina. La idea de un carácter español hecho de orgullo, amor a la libertad y a la independencia, individualismo, sentimiento monárquico y religioso-, presente ya en la obra de Masdeu, adquiere ahora mayor consistencia, como ha apuntado Morales $\mathrm{Moya}^{27}$ (aunque Lafuente lo entiende como un proceso de afirmación histórica y sin las connotaciones metafísicas del debate posterior de entresiglos).

El desarrollo de la historia nacional en España viene acompañado del auge simultáneo de la historia particular, género -en el sentir de Muñoz Romero, que realizó el censo de esta producción en $1858^{28}$ - donde ninguna otra nación superaba a la española en número. La unidad y pluralidad de memorias es característico, por tanto, del reinado de Isabel II. La historia de España es con-

\footnotetext{
títulos figuran en MORENO ALONSO, 1985, p. 84 y JOVER, 1991a, pp.164-165. Una aproximación a los contenidos de esas historias, leídas conjuntamente, en ALVAREZ JUNCO, 2001, pp. 195-226.

${ }_{26}$ JOVER, J.M.: «Centralismo y nacionalismo. La idea de España en la época de los nacionalismos europeos», recogido en su La civilización española, pp. 140-91 (las referencias concretas a la Historia de Lafuente en págs. 155-163); "Caracteres del nacionalismo español, 1854-1874», en Posibilidades y límites de una bistoriografía nacional, Madrid, Instituto Germano-Español de Investigación de la Goerres-Gesellschaft, 1984, pp. 360-361.

27 MORAles MOYA, 1993, p. 626.

${ }^{28}$ MUÑoz Romero, T.: Diccionario bibliográfico-bistórico de los antiguos reinos, provincias, ciudades, villas, iglesias y santuarios de España, Madrid, 1858.
}

Hispania, LXV/1, núm. 219 (2005) 281-306 
templada como una progresión hacia la unidad, pero se exalta al tiempo la importancia de las comunidades locales para comprender la civilización española, como subrayó entonces Gonzalo Morón. La mirada romántica de los viajeros europeos tenderá, por el contrario, a convertir fácilmente la comunidad de cualquier lugar remoto de la geografía española en la llave que podía abrir los secretos del país, contribuyendo así a forjar el mito de la España diferente y la visión de España como problema (la dicotomía España real/España oficial omnipresente en la literatura critica finisecular del 98) ${ }^{29}$.

El País Vasco constituyó una especial atracción para esas miradas curiosas e impertinentes. Buena parte de los mitos románticos vascos (el fantasma del separatismo incluido) obedecen a esa mirada del otro, pero no falta una historiografía vasca nativa de carácter afrancesado o liberal, según manifiestan tempranamente Lemonauría u Hormaeche, discípulos de Alberto Lista, principales exponentes de un fuerismo liberal defensor de la compatibilidad entre Constitución y Fueros, que no recoge sino el espíritu doctrinario de 1830 cifrado en el pacto Revolución-Tradición ${ }^{30}$. El mismo espíritu que preside la labor historiográfica y política de Yanguas y Miranda, conducente en Navarra a la ley de 1841, clara traducción por encima de formulaciones jurídicas del nuevo pactismo liberal ${ }^{31}$

Tampoco en Cataluña falta ese horizonte doctrinario. Se encuentra en las motivaciones intelectuales de Cortada, de Marti d'Eixalá, de Llorens i Barba ${ }^{32}$, y en la voluntad de participación de la élite catalana en la construcción del marco liberal en España, bases de lo que Fradera ha denominado el doble patriotismo catalán ${ }^{33}$. Esa misma lógica - aunque con una mayor sensibilidad por las instituciones, aún vivas, a diferencia de Cataluña - se registra en el País Vasco y explica en buena medida el sucesivo retraso del arreglo foral vascongado, manifestación entonces no tanto de una supuesta debilidad del Estado español sino del compromiso efectivo de la élite vasca en la política española (el caso de Egaña, muy implicado en el triunfo del liberalismo español y altavoz temprano de

29 Burns Marañón, T.: Hispanomanía, Barcelona, Plaza \& Janés, 2000, pp. 237-238.

30 SÁNCHeZ-Prieto, J.M.: «Permanencia y quiebra del Antiguo Régimen: el debate vasco durante la primera mitad del siglo XIX», en Cuadernos de Alzate (Madrid), 23 (2000), pp. 97-118.

31 SÁNCHEZ-Prieto, J.M. y J.L. NieVA: «La aventura política e intelectual de Yanguas y Miranda", en Cuadernos del Marqués de San Adrían (Tudela), 1 (2002), pp. 11-40.

32 GHANIme, A.: Joan Cortada: Catalunya $i$ els catalans al segle XIX, Barcelona, Publicacions de l'Abadia de Montserrat, 1995. RourA, J.: Ramon Martí d'Eixelà i la filosofia catalana del segle XIX, Barcelona, Publicacions de l'Abadia de Montserrat, 1980. ANGlès I CERvelló, M.: El pensament de F. Xavier Llorens $i$ Barba i la fil, Barcelona, Institut d'Estudis Catalans, 1998. Cúscó, J.: Francesc Xavier Llorens $i$ Barba $i$ el pensament fil: el pensament filosòfic a Catalunya, Barcelona, Publicacions de l'Abadia de Montserrat, 1999.

33 Fradera, J.M.: Cultura nacional en una societat dividida. Patriotisme i cultura a Catalunya, 18381868, Barcelona, Curial Edicions Catalanes, 1992. «El proyecto liberal catalán y los imperativos del doble patriotismo», en Ayer (Madrid), 35 (1999), pp. 87-100. «La política liberal y el descubrimiento de una identidad distintiva de Cataluña (1835-1865)», en Hispania (Madrid), 205 (2000), pp. 673-702.

Hispania, LXV/1, núm. 219 (2005) 281-306 
la «nacionalidad» vasca, es singularmente ilustrativo) así como de los propios límites de la voluntad centralizadora del liberalismo español antes de 1875 .

Si durante la primera mitad del siglo XIX pudo cuajar la idea de una España plural en determinados sectores del liberalismo vasco-navarro y catalán (antes de adquirir nuevas formulaciones en clave regionalista, federal o iberista) es porque tuvo audiencia dentro del liberalismo español gobernante, al manifestar las mismas raíces intelectuales y compartir con ellos un mismo lenguaje (el liberalismo romántico de 1830). El hecho de que partir de 1850 (las mismas fechas que Eugen Weber maneja para el caso francés ${ }^{34}$ ) comenzase a adquirir mayor fuerza y realidad la idea de una España uniforme, no permite identificar de un modo general a los moderados con la vía centralista y unitaria, ni atribuir a este momento y por la vía moderada - como pretende Borja de Riquer- la imagen de una España eterna y única identificada exclusivamente con Castilla ${ }^{35}$. Tal vez sea preciso calibrar de nuevo (como hizo Azaña en otro tiempo ${ }^{36}$ ) la distinción entre liberalismo doctrinario y moderantismo político, y sus implicaciones a propósito de la identidad.

El doctrinarismo liberal de cuño francés desde su capacidad de aunar memoria histórica y praxis política va a activar las conciencias vasca y catalana. La figura y la obra historiográfica de Víctor Balaguer es una buena muestra de ello en Cataluña ${ }^{37}$. Posteriormente, la experiencia del proceso de cambio político y social afectará a la conciencia liberal de algunos intelectuales, como sucedió a Donoso Cortés en el marco español ${ }^{38}$, haciendo crecer la pura nostalgia hacia el pasado y la exaltación del mundo originario y la tradición específica en contraposición a los valores revolucionarios y liberales. Milá i Fontanals y Pau Piferrer marcan una tendencia que fructificará dentro de la Renaixença en la historiografía de Antonio Bofarrull ${ }^{39}$, y que se recoge más tarde fuera de la cultura catalana — relanzando la cultura española - en personalidades como Menéndez y Pelayo, discípulo de Milá. Los efectos negativos de la industrialización - ha consignado Fradera - pesan en la mitificación de las instituciones tradicionales del mundo rural, la masía, como marco de organización económica y familiar ${ }^{40}$. La misma

34 WeBer, E.: La Fin des terroirs. París, Fayard, 1983.

35 DE RuQuer, B.: Identitats contemporànies: Catalunya i Espanya, Vic, Eumo, 2000, pp. 62, 75 (versión castellana: Escolta Espanya. La cuestión catalana en la época liberal, Madrid, Marcial Pons', 2002).

36 AZAÑA, M. «Tres generaciones del Ateneo», en Obras Completas, I, México, Oasis, 1966, p. 621.

37 Sobre Víctor Balaguer véanse los estudios de E. Miralles, M. Cuccu, J.M. Fradera, J. Palomas, R. Roca y P. SANTVICEnS recogidos en M. JORBA y otros: El segle Romàntic. Actes del Col.loqui sobre el Romanticisme, Vilanova, Biblioteca Museu Balaguer, 1997.

38 SÁNCHEZ-PrIETO, J.M.: Estudio preliminar a J. DONOSO CORTÉS, Ensayo sobre el catolicismo, el liberalismo y el socialismo, Salamanca, Almar, 2003

39 JORBA, M.: Manuel Milà $i$ Fontanals en la seva època, Barcelona, Curial Ediciones Catalanes, 1984. Carnicer, R.: Vida y obra de Pablo Piferrer, Madrid, CSIC, 1963. Ginebra i Serrabou, J.: Antoni de Bofarrull i la Renaixença, Reus, Associació d'Estudis Reusencs, 1988.

40 FRADERA, J.M.: «El huso y la gaita (Un esquema sobre cultura y proyectos intelectuales en la Cataluña del siglo XIX», en Ayer (Madrid), 40 (2000), pp. 39-40, 43. 
tendencia puede notarse en el País Vasco con la exaltación del caserío de mano de la generación de Antonio Trueba, donde se advierte la influencia de Le Play ${ }^{41}$.

\section{La alternativa democrático-republicana}

La caída de la monarquía isabelina evidencia una crisis ideológica del Estado, a la que se enfrentó el Sexenio proporcionando diversas respuestas, como fueron la monarquía democrática o la república federal. La nueva España plural de los federales buscó cimiento en las ideas proudhonianas de Pi i Margall (la nación como pacto político democrático, el pactismo federal ${ }^{42}$. En ellas hunde sus raíces progresistas el catalanismo y encuentra también eco, desde mediados de siglo, el sueño de la Unión Ibérica —la unión de España y Portugal- alimentado asimismo por Castelar en el momento en que se producen las unificaciones italiana y alemana. La dimensión de historiador de Pi i Margall se hará evidente, con el auxilio de su hijo, en la publicación póstuma de su Historia de España en el siglo XIX (1902).

Las turbulencias políticas del sexenio no permitieron la elaboración de una historia nacional en clave democrática y republicana. A lo más que se llegó fue a trasladar por vía de urgencia a la escuela una cierta imagen republicana de España. Destaca en ese sentido el Compendio de Historia de España de Moreno Espinosa, cuyas primeras ediciones datan de 1871 y 1873, permaneciendo luego durante la Restauración entre los manuales más difundidos. El papel que habían adquirido los visigodos durante la época doctrinaria es contrapesado aquí por los iberos: los primeros pobladores de la península y que, tras su fusión con los celtas, lograron la unidad ibérica, aunque no se rigieran por un único gobierno. Moreno Espinosa combate expresamente la idea de que la monarquía visigoda llegara a realizar nunca la «verdadera unidad nacional, la fusión entre españoles y godos», escribe ${ }^{43}$. De la «raza celtíbera» queda como testimonio vivo su lengua, el idioma euskaro, afirma Moreno Espinosa, recogiendo el eco del debate europeo sobre lo vasco, que comenzaba en esos momentos a rearmar la tesis iberista, formulada por Humboldt, con las aportaciones de la antropología física y la lingüística comparada ${ }^{44}$.

${ }^{41}$ ELORZA, A.: «Ideología nacionalista y Antiguo Régimen», en Industrialización y nacionalismo, Barcelona, Universidad Autónoma, 1985, p. 405. ASSIER, F.: «Le Play et la famille souche des Pyrénées», Annales ESC (París), 39 (1984), pp. 495-512.

42 DOMÈNECH, J.: El pensament de Pi i Margall com a base del seu federalisme, Tarragona, Universidad Rovira i Virgili, 1998. MOLAS, I. (ed.): Francisco Pi i Margall y el federalismo, Barcelona, Institut de Ciències Polítiques i Socials, 2003.

${ }_{43}$ Moreno EsPinOSA, A.: Compendio de Historia de España [1871], $2^{\mathrm{a}}$ ed. Cádiz, 1873, pp. 4-5 y 27.

44 SÁNCHEZ-PRIETO, J.M.: El imaginario vasco. Representaciones de una conciencia bistórica, nacional $y$ política en el escenario europeo, 1833-1876, Barcelona, Ediciones Internacionales Universitarias, 1993 , pp. 818-851.

Hispania, LXV/1, núm. 219 (2005) 281-306 
El regreso de los iberos al debate intelectual y político favorecerá asimismo las tesis republicano-fueristas, que preconizan dentro y fuera del País Vasco la extensión de los fueros a toda España. El mismo Cánovas hizo referencia a ellas en 1873. Más allá de la fuerza de estas ideas, no se oculta su simbolismo de carácter regeneracionista, visible ya en la tesis doctoral de Bahamonde en 1868. Como los visigodos, la monarquía isabelina había sucumbido bajo el peso de la corrupción, y tras ella debían surgir de nuevo las virtudes del pueblo originario, que resucita multiforme ${ }^{45}$. Imagen que se recoge paralelamente en buena parte de Europa como fundamento del mito de las dos naciones.

Se puede establecer el paralelo y la diferencia con Francia. Al descubrimiento y triunfo de los galos en Francia - nos ancêtres les gaulois, portadores de los valores nacionalizadores de la III República ${ }^{46}$ - , que preside el rearme del nacionalismo francés tras la derrota de Sedán, se corresponde en España el fracaso de los iberos, y con ellos de la vía democrática para el progreso de una España plural ${ }^{47}$.

\section{Los cambios de la Restauración}

Con la Restauración canovista el centralismo español adquirió una dimensión real ${ }^{48}$. La abolición de los fueros vascongados fue todo un símbolo. Cánovas llegó a realizar lo que no se atrevió a hacer Godoy, y pudo asimismo presentarse como el último doctrinario (el binomio monarquía-nación, el acento en la constitución histórica). Cánovas no bebe, sin embargo, en simples fuentes del pasado. Su concepto de nación (1882) se encuentra inmerso en el debate europeo coetáneo que ilustran Renan y Mommsen, considerando la cuestión a la luz de la lucha histórica entre los pueblos germanos y latinos por la hegemonía de Europa ${ }^{49}$. El proyecto político de Cánovas atiende a esas inquietudes y a sus propias convicciones como historiador consagrado de la decadencia española. No sorprende su nombramiento como director de la Academia de la Historia en 1882, aunque no sea Cánovas el único ni el principal referente del pano-

45 BAHAMONDE, D.: Orígenes de las nuevas nacionalidades que inician la reconquista durante los siglos VIII y IX de la Península Ibérica, Madrid, 1868, pp. 25-26.

46 CARbonell, Ch.O.: «Après 1870: régénérescence de la France et renaissance de la Gaule», en P. Viallaneix y J. Ehrard (eds.): Nos ancêtres les Gaulois. Actes du Colloque International de Clermont-Ferrand, Clermont-Ferrand: Publications de la Faculté des Lettres et Sciences Humaines, 1982, pp. 391 y ss. AMALVI, Ch.: De lart et de la manière d'accommoder les héros de l'bistoire de France. Essais de mytbologie nationale, París, A. Michel, 1989.

47 Sobre el proyecto iberista, véase Jover, 1991a, pp. 177-191; Álvarez JunCO, 2001, pp. 524-531.

48 Fernández Almagro, M.: Cánovas: su vida y su política, Madrid, Tebas, 1972. Comellas, J.L.: Cánovas del Castillo, Barcelona, Ariel, 1997.

49 Jover, J.M.: Prólogo a YLLÁN, E.: Cánovas entre la bistoria y la política, Madrid, Centro de Estudios Constitucionales, 1985, pp. xiii-xvi; Jover, "Restauración y conciencia histórica», en España. Reflexiones sobre el ser de España, Madrid, Real Academia de la Historia, 1997, p. 354.

Hispania, LXV/1, núm. 219 (2005) 281-306 
rama historiográfico de la Restauración, definido por la irrupción de los nuevos historiadores llamados positivistas ${ }^{50}$, que van a asegurar la tendencia a la profesionalización de la historia iniciada en la época isabelina: Hinojosa, Fita, Codera y Menéndez Pelayo, como figuras señaladas en un primer momento; Altamira y Menéndez Pidal, después ${ }^{11}$.

Menéndez Pelayo fue, sin duda, la figura más destacada del primer grupo y marcó el debate intelectual de la Restauración. La polémica de la ciencia española con los krausistas, incidiendo en el impacto de la Inquisición en el desarrollo científico y filosófico español, remite a la antigua polémica del siglo XVIII. Su ansia de resaltar la especificidad española convertirá más tarde a Menéndez Pelayo en un referente cultural del tradicionalismo. El españolismo de Menéndez Pelayo se funda en la defensa de un pensamiento moderno nativo español, el humanismo renacentista de Luis Vives. En consecuencia, su rechazo del pasado nacional a partir del XVIII se debe a la importación de doctrinas foráneas (racionalismo francés, panteísmo alemán), responsables de la introducción artificial de ideas revolucionarias que, según considera, han destruido a la altura de los años 1870 la autenticidad de la cultura española. En la definición de la identidad nacional de Menéndez Pelayo predominan los argumentos histórico-culturales sobre los esencialistas, aunque se encuentren entremezclados. $\mathrm{Y}$ hay que hacer notar que en el plano político Menéndez Pelayo se movió siempre en la órbita del partido conservador, y que su compromiso con la monarquía constitucional, su respeto por la neutralidad de la escuela y su campaña por establecer la modernidad de la cultura española, le granjearon la enemistad de los carlistas ${ }^{52}$.

Fuera del ámbito de influencia de algunas órdenes religiosas en la enseñan$z a$, es difícil encontrar manifestaciones de una historiografía savante propiamente integrista ${ }^{53}$. El acento en la religión como un elemento definidor de la identidad nacional no es original ni exclusivo del integrismo católico ni del conservadurismo. Otra cosa es la identificación entre identidad nacional y uni-

so Carbonell, Ch. O.: «L'histoire dite positiviste en France», Romantisme (París), 21-22 (1978), pp. 173-85.

s1 GUINARD, P.: «Espagne», en Histoire et Historiens depuis Cinquante ans. Méthodes, organisation et résultats du travail historique de 1876 à 1926 [1927-28], $2^{\text {a }}$ ed. Nueva York, P. Burt, 1971, pp. 107-138.

52 BOYD, C.P.: Historia Patria: politics, bistory, and national identity jn. Spain, 1875-1975, Princeton, Princeton University Press, 1997, pp. 103-104 (trad. española: Barcelona, PomaresCorredor, 2000). SÁNCHEz REYES, E.: Don Marcelino Menéndez Pelayo: biografía del último de nuestros bumanistas, Barcelona, Aedos, 1959. FOARD, D.W.: «The Spanish Fichte: Menéndez y Pelayo», en Journal of Contemporary History (Londres), 14 (1979), pp. 83-97. RevUelTA, M. (ed.): Menéndez Pelayo. Hacia una nueva imagen, Santander: Sociedad Menéndez Pelayo, 1983.

53 Destacan la Historia de España (1876) y los Elementos de historia crítica de España (1892) del catedrático de universidad MERRY Y COLÓN, y el Compendio de Historia de España (1889) redactado por el mismo autor con la colaboración de MERRY Y VILLALBA como texto de enseñanza para los seminarios y colegios católicos, que no son sino muestras de una historia de la Iglesia en un contexto nacional (BOYD, 1997, pp. 108-111; ALVAREZ JUNCO, 2001, pp. 417-431).

Hispania, LXV/1, núm. 219 (2005) 281-306 
dad católica, a la que pudo contribuir el propio Menéndez Pelayo al polemizar sobre la consustancialidad de la nación española y el sentimiento católico.

El progreso de la España uniforme durante la Restauración desencadenó la ofensiva regionalista. La reacción intelectual de la élite vasco-navarra tras la abolición foral, marcada por el signo del pesimismo, tendrá repercusión en Cataluña, como observó Tubino en 1880 al historiar los orígenes del renacimiento catalán ${ }^{54}$. La pretensión de cientificidad de la nueva generación de historiadores catalanes (los Bofarrull, Sanpere i Miquel, Rubió i Ors, Quadrado o Pella) no oculta su voluntad catalanizadora y, al igual que sucede con otros intelectuales, comienza a politizarse el sentimiento de pertenencia reivindicándose instituciones y poder político. Manifestación de ello fue la Història de Catalunya (1887) de Aulèstia i Pijoan (dos volúmenes en catalán), en puridad la primera historia nacional catalana ${ }^{55}$.

El estatalismo liberal va a abrir las puertas, en el fin de siglo, al nacionalismo antiliberal de aires, una vez más, franceses. La impronta de Taine y Barrès se encuentra en historiadores euskaros como Campión, que en su juventud se había movido en la órbita democrática del 68. Se establece un nuevo diálogo con el pensamiento contrarrevolucionario desde el camino de vuelta del positivismo, como hicieron Renan y Taine, desencantados frente al desarraigo del hombre contemporáneo y agobiados por el peso del Estado ${ }^{56}$. Y ese mismo nacionalismo antiliberal es el que aviva en Cataluña los postulados corporativistas de un Torres i Bages, que se imponen a la perspectiva liberal-republicano-regeneracionista de Almirall formulada en $L^{\prime} E s p a g n e$ telle qu'elle est $(1887)^{57}$.

La distancia entre los casos vasco y catalán se hará patente, sin embargo, en el cambio de siglo. Ambos protagonizarán un divorcio con lo español, pero de

54 TUBINO, F.: Historia del renacimiento literario contemporáneo en Cataluña, Baleares y Valencia, Madrid, 1880, pp. 179-180.

ss ANGUeRA, P.: «Nacionalismo e historiografía en Cataluña», en ForCadell, C. (ed.): Nacionalismo e bistoria, Zaragoza, Institución Fernando el Católico, 1998, p. 88 (también en Hispania, 209, 2001). ANGUERA, P.: Escrits politics del segle XIX. Catalanisme cultural, Vic, Eumo, 1998; Literatura, pàtria $i$ societat. Els intel.lectuals i la nació, Vic, Eumo, 1999.

${ }_{56}$ RICHARD, E.: Ernest Renan, penseur traditionaliste?, Aix-en-Provence, Presses universitaires d'Aix-Marseille, 1996. LÉGER, F.: Monsieur Taine, París, Critérion. 1993. GaSPARINI, E.: La pensée politique d'Hippolyte Taine, Aix-en-Provence, Presses universitaires d'Aix-Marseille, 1993. STERNHELL, Z.: Maurice Barrès et le nationalisme français, $2^{\mathrm{a}}$ ed. París, Fayard, 2000. FRANDON, I.M.: Barrès tel qu'en lui-même: modernité et déracinement, Fontainebleau, La Pirole, 1998. LóPeZ ANTÓN, J.J.: Arturo Campión, entre la bistoria y la cultura, Pamplona, Institución Príncipe de Viana, Fundación Sabino Arana, 1998.

57 FigUERES, J.M.: Valentí Almirall, forjador del catalanisme, Barcelona, 1990. PiCH I MrTJANA, J.: Valentí Almirall $i$ Llozer, 1841-1904 i la gènesi del catalanisme polític, tesis doctoral leída en la Universidad Pompeu Fabra, 1998. GILABERT, J.J.: «Valentí Almirall y la generación del 98», en Revista Hispánica Moderna (Nueva York), XIIV, 2 (1991), pp. 217-225. BONET I BALTÁ, J. y C. MARTÍ: L'integrisme a Catalunya. Les grands polèmics, 1881-1888, Barcelona, Vicens Vives, 1990. VALENTí FIOL, E.: El primer modernismo literario catalán y sus fundamentos ideológicos, Barcelona, Ariel, 1973. 
carácter distinto: político en un caso, cultural en el otro. El acento vasco, a raíz de la pérdida de los fueros, de Sagarmínaga a Olóriz, está puesto en el abandono de la política española ${ }^{58}$, y se recoge en el opúsculo de Sabino Arana, Bizcaya por su independencia (1892), pretendiendo hacer memoria de la historia (aunque la evolución del universo mental de Arana llegara a relativizar esa primera posición $\left.{ }^{59}\right)$. En el ámbito catalán lo que va producirse es una ruptura de la intelectualidad catalana con la cultura española ${ }^{60}$. Ese es el objetivo del modernisme catalán. En adelante, como ha explicado Vicente Cacho, la comunicación Madrid-Barcelona no será ya directa sino únicamente a través del otro vértice del triángulo europeo: París. A comienzos del siglo XX, el modernismo y la vinculación a éste de Prat de la Riba establece la principal diferencia entre Cataluña y el País Vasco, crucial para el desarrollo de los nacionalismos respectivos ${ }^{61}$.

En este contexto, de evolución del regionalismo al nacionalismo, y de positivismo historiográfico, las nuevas historias generales de España elaboradas durante la Restauración pierden buena parte de su eficacia nacionalizadora al ser obras colectivas realizadas por especialistas antes que de autor. Destaca la que dirigió Cánovas del Castillo, escrita por individuos de la Real Academia de la Historia (Historia general de España, 1890-94) en 18 volúmenes. La obra, ambiciosa, desigual y difícil de realizar, quedó definitivamente interrumpida con la muerte de Cánovas. En lo fundamental no se encuentran especiales diferencias con la obra de Lafuente, sobresaliendo de nuevo el acento visigodo. No es ésta evidentemente la historia que esperaba el catalán Ubach cuando en 1888 criticó abiertamente el modelo de Historia de Lafuente («con respecto a Cataluña la historia general de España está por construirse», valoraba), pero llama la atención en la obra coordinada por Cánovas que el momento cumbre de los Reyes Católicos fuese encargado a Víctor Balaguer, catalanista progresista, que no deja de exaltar el enlace que "trajo a España la unidad histórica». Con todo, sostiene, fue un «error político» dejar que Castilla tomara la preponderancia que alcanzó, pero en el momento de la unión «ninguna razón abonaba esta supremacía» ${ }^{62}$.

El declive de las historias nacionales, en su capacidad de forjar y movilizar la conciencia nacional, hace que ese papel antes asignado a la historiografía vaya a corresponder ahora a la literatura. Sobresalen en ese sentido los Episodios nacionales de Pérez Galdós, compartiendo tarea a partir de la tercera serie con la

58 Nieva, J.L.: La idea euskara de Navarra, 1864-1902, Bilbao, Fundación Sabino Arana, 1999 , pp. 247-311.

59 CORCuerA, J.: La patria de los vascos. Orígenes, ideología y organización del nacionalismo vasco, Madrid, Taurus, 2001. Elorza, A.: Un pueblo escogido, Barcelona, Crítica, 2001.

60 Marfany, J.L.: La Cultura del Catalanisme, Barcelona, Empúries, 1995.

61 CACHO VIU, V.: El nacionalismo catalán como factor de modernización, Barcelona, Quaderns Crema, 1998. Balcellis, A. y AinAud De LASARTE, J.M.: Enric Prat de la Riba. Obra completa, 18981905, Barcelona, Edicions Proa, Institut d'Estudis Catalans, 1998.

${ }^{62}$ Citado por PEIRó, 1995, pp. 159-163. 
novela histórica del 98. Los Episodios representan también, como ha hecho notar Jover, la vía fundamental de incorporación de la experiencia republicana de 1873 a la memoria nacional ${ }^{63}$. Esa desarticulación de historia y memoria, que consagra en el cambio de siglo la ficcionalización de la memoria por medio de la literatura, también se registra en el País Vasco, en parte debido a Unamuno, cuyo concepto de intrabistoria no se agota en el mito de las dos Españas sino que acabará por fortalecer el mito vasco, como ha señalado Juaristi ${ }^{64}$.

\section{EL MITO DE LAS DOS ESPAÑAS}

De las historias nacionales al mito o a las imágenes de las dos Españas. Ese proceso se entiende a la luz de la crisis del positivismo, según ha hecho ver Vicente Cacho, y no es algo exclusivamente español sino fundamentalmente europeo. El mito de las dos naciones se convirtió hacia la década de los 70 del siglo XIX en un lugar común del lenguaje culto europeo, tomando el relevo al mito de la decadencia ${ }^{65}$.

El mérito de Costa en la España de 1898 radica en haber popularizado la imagen de las dos Españas, hasta entonces patrimonio de unos pocos, $\mathrm{y}$ hacer de ella referencia inexcusable para el análisis de la realidad nacional, pero no hay grandes aportaciones personales. Costa reproduce en términos casi idénticos el modelo francés de contraponer una nación sana (la nación de subsuelo, sin problemas ni fisuras, la nación del porvenir) y una minoría política dominante, corrupta e ineficiente (la nación en el poder). 1898 debía significar para España lo que 1870 había supuesto para Francia, un revulsivo nacionalizador, el nacimiento de una nueva España ${ }^{66}$. Su decepción inmediata queda reflejada en Oligarquía y caciquismo (1902), texto canónico del anticanovismo militante. El espejismo de que España pudiera reproducir el modelo francés se ha desvanecido ${ }^{67}$. El rechazo a la obra de Cánovas empuja al divorcio de los intelectuales con los políticos ${ }^{68}$. La literatura se convierte en un acto de protesta.

${ }^{63}$ JOVER, 1984, pp. 361, 368, y Realidad y mito de la primera república, Madrid: Espasa Calpe, 1991 (b), pp. 205-206.

${ }^{64}$ JUARISTI, J.: El linaje de Aitor. La invención de la tradición vasca, $2^{\mathrm{a}}$ ed. Madrid, Taurus, 1998, pp. 215-68; El bucle melancólico. Historias de nacionalistas vascos, Madrid, Espasa Calpe, 1997, pp. 65-100.

65 CACHO VIU, V.: «La imagen de las dos Españas», en Revista de Occidente (Madrid), 60 (1986), pp. 49-77.

66 CACHO VIU, V.: «Francia 1870-España 1898», en 1898: ¿desastre nacional o impulso modernizador?, número monográfico de Revista de Occidente (Madrid), 202-203 (1998), pp. 9-42. Recogido también en su Repensar el noventa y ocho, Madrid, Biblioteca Nueva, 1997, pp. 77-115.

67 MATEOS Y DE CABO, O.I.: Nacionalismo español y europeísmo en el pensamiento de Joaquín Costa, Zaragoza, Institución Fernando el Católico, 1998.

68 VILlaCORTA BAÑOS, F.: Profesionales y burócratas: estado y poder corporativo en la España del siglo XX, 1890-1923, Madrid, Siglo Veintiuno, 1989.

Hispania, LXV/1, núm. 219 (2005) 281-306 
El renacimiento literario de la generación del 98 conlleva una reinvención de España. El dolor del 98 produce el alumbramiento de Castilla y se sientan las bases de un nacionalismo español de nuevo cuño: el alma de Castilla como esencia del alma de España ${ }^{69}$. Aunque su papel sea inferior al de los literatos, a ello contribuyeron también los historiadores profesionales: Altamira y Menéndez Pidal. Altamira ${ }^{70}$, discípulo de Giner como Costa, había manifestado en el prólogo a su Psicología del pueblo español (1901) la misma esperanza costista en la reacción española tras el desastre. En su ensayo latía asimismo el afán que tuvo Masdeu en el siglo XVIII de revisar y refutar las cualidades negativas falsamente atribuidas a los españoles a través de los siglos, lo que reiterará representando a España en el Primer Congreso Internacional de Ciencias Históricas (1901). Su Historia de España y de la civilización española (1909-1911, 4 vols.), aunque niegue valor científico a Lafuente, continúa concibiendo a la nación, protagonista de la historia, como una unidad orgánica que evoluciona según una marcha continua y ascendente, y en cuyo espíritu hay que penetrar. Para Altamira la raíz de la grandeza del pasado español se encuentra en cualidades hondas del carácter nacional que afloran en hombres de todos los tiempos ${ }^{71}$. El positivismo de Altamira no se desprende del idealismo krausista. Compartiendo la preocupación por la enseñanza de Giner, Altamira fue el introductor en España de la metodología de Langlois y Seignobos, llegando a la convicción de que escribir y enseñar historia podía ser un acto de patriotismo, a lo Lavisse ${ }^{72}$, que dispusiera los fundamentos de la España nueva, sin plegarse al pesimismo último de Costa y del $98^{73}$.

Con no menos sentido patriótico y aplicando el método filológico-crítico a las crónicas y textos literarios castellanos, Menéndez Pidal ${ }^{74}$ - discípulo de Menéndez Pelayo y Codera - se entregó a sondear lo más profundo del alma popular, la roca viva donde toda construcción duradera ha de sentar sus ci-

69 FoX, I.: «La comunidad imaginada», en su La invención de España. Nacionalismo liberal e identidad nacional, Madrid, Cátedra, 1997, pp. 111-174. VARELA, J.: «Castilla, mística y guerrera», en su La novela de España. Los intelectuales y el problema español, Madrid, Taurus, 1999, pp. 145-176.

70 RAmos, V.: Rafael Altamira, Madrid, Alfaguara, 1968. AlbEROLA, A. (ed.): Estudios sobre Rafael Altamira, Alicante, Instituto de Estudios Juan Gil-Albert, 1988. MARAVALL, J.A.: «La concepción de la Historia en Altamira», en Cuadernos Hispanoamericanos (Madrid), 477-478 (1991), pp. 13-48.

71 MORAles MOYA, 1993, p. 646. Pellistrand, B.: «Escribir la historia de la nación española: proyectos y herencia de la historiografía de Modesto Lafuente y Rafael Altamira", en Investigaciones bistóricas (Valladolid), 17 (1997), pp. 137-159.

72 NORA, P.: «Lavisse instituteur national», en Les lieux de la mémoire I: La République, París, Gallimard, 1984, pp. 247-289; "L'Histoire de France de Lavisse», en Les lieux de la mémoire II. La Nation*, París, Gallimard, 1986, pp. 317-375.

73 CheyNe, G.J.G. ed.: El renacimiento ideal. Epistolario de Joaquín Costa y Rafael Altamira, Alicante, Instituto de Estudios Juan Gil-Albert, 1992. AlTAmIRA, R. Ideario político, Valencia, Biblioteca Valenciana, 2001.

74 Pérez Villanueva, J.: Ramón Menéndez Pidal. Su vida y su tiempo, Madrid, Espasa Calpe, 1991. PÉrez PASCUAL, X.I.: Ramón Menéndez Pidal, ciencia y pasión, Valladolid, Castilla y León, 1998. 
mientos, consideraba, en busca de la verdadera tradición española, llegando a la conclusión - más política que científica- de que existía un ideario tradicional convergente con los principios rectores del liberalismo. Desde ese prisma, Menéndez Pidal defiende la hegemonía de Castilla entre los pueblos peninsulares: "en la individualista España, Castilla abriga en su masa popular un más eficiente individualismo", sentencia. La España del Cid constituirá para Menéndez Pidal el referente de la permanente identidad de los españoles, para así entender mejor las cimas y depresiones de la historia española, según hizo considerar después de la guerra civil (Los españoles en la historia, 1947).

Frente al pesimismo nitzscheano del 98 se alza el empeño positivo de la generación de 1914 de Ortega y Azaña, que transformará las constataciones desilusionadas costistas de la inexistencia de la segunda España - la nación de subsuelo- en un reto desde el cual proponer un proyecto de modernización para el país ${ }^{75}$. El afloramiento de la nueva España y la institucionalización de la vida española exigían primero la restitución del pasado, despreciado por la hipercrítica del 98 que fue absolutamente estéril en lo político, como recalcó Azaña ${ }^{76}$. En ese sentido destaca la crítica realizada por Azaña (1921-30) al Idearium español de Ganivet, quien se había permitido rechazar la mayor parte de la historia moderna de España calificándola de «falsa» y «contradicción política» por no ajustarse a su previa definición de españoles ${ }^{77}$. Contra el peligro de «alterar frívolamente las representaciones históricas» (según enjuiciaba Azaña el trabajo de Ganivet), opuso Ortega el concepto de razón histórica, vuelta hacia el futuro, que preside su pensamiento historiográfico a partir de España invertebrada: «las naciones se forman y viven de tener un programa para el mañana» ${ }^{78}$.

La dictadura de Primo de Rivera, erigido personalmente en el cirujano de hierro costista, truncará las actitudes iniciales a favor de una monarquía democrática de la generación de 1914, que apostará desde ese momento por la vía republicana para hacer surgir la segunda España, la nueva España. El pacto monarquía-dictadura volvía a sumergir a España en las oscuridades del Antiguo Régimen, obligando luego a proclamar la necesidad de la revolución pendiente. La imagen se recoge también del otro lado, como manifiesta el auge del

75 RABATÉ, J-C. (coord.): Crise intellectuelle et politique en Espagne à la fin du XIXe siècle, París, Editions du Temps, 2000. SÁNCHEZ ILLÁN, J.C.: La nación inacabada: los intelectuales y el proceso de construcción nacional (1900-1914), Madrid, Biblioteca Nueva, 2002. CACHO VIU, V.: Los intelectuales y la política. Perfil público de Ortega y Gasset, Madrid, Biblioteca Nueva, 2000. Molinuevo, J.L.: Para leer a Ortega, Madrid, Alianza, 2002. Julı́A, S.: Manuel Azaña, una biografía política: del Ateneo al Palacio Nacional, Madrid, Alianza, 1990. VelARDE, J. y F. MORÁN, Manuel Azaña, Barcelona, Ediciones B, 2003.

${ }^{76}$ Juliá, S.: "Manuel Azaña y la crítica política del 98», en AzAÑA, M. iTodavía el 98!, Madrid, Biblioteca Nueva, 1997, pp. 13-37.

77 AZAÑA, M.: «El 'Idearium' de Ganivet (1921-1930), en Obras Completas, I, pp. 568-619. Olmedo, M.: El pensamiento de Ganivet, Granada, Diputación de Granada, 1998.

78 MARICHAL, J.: «Ortega en la historia de su España», en su El secreto de España. Ensayos de historia intelectual y política, Madrid, Taurus, 1995, pp. 213-222. 
tradicionalismo y el mismo desarrollo de la escuela católica al amparo de la dictadura ${ }^{79}$.

El mito de las dos Españas reviste así una nueva figura, la de la vieja pugna entre Antiguo y Nuevo Régimen. Fue, en cierta forma, la consecuencia de la desaparición del siglo XIX, operada conjuntamente por el 98 , en su cruzada anticanovista, y por la ficcionalización de toda la época anterior a la Restauración que lleva a cabo la obra de Galdós ${ }^{80}$. En el nuevo escenario juega un papel relevante Ramiro de Maeztu, ligado anteriormente a Ortega en la preparación de un nuevo liberalismo ${ }^{81}$. Como ideólogo de Acción Española, fundada sobre el modelo de la Acción francesa de Maurras ${ }^{82}$, Maeztu se levantará En defensa de la bispanidad (1932), de un concepto de hispanidad entendida como comunidad espiritual de las naciones hispánicas unidas por lo católico que se alejaba del concepto de civilización española propio de la tradición liberal, tal y como se había formulado desde Tapia hasta Altamira ${ }^{83}$. En 1934, Acción Española publicó una Historia de España compuesta enteramente por fragmentos de la obra de Menéndez Pelayo.

Es preciso subrayarlo. No existe verdaderamente una escuela tradicionalista en España. Donoso Cortés, Menéndez Pelayo o Maeztu —a menudo señalados como lumbreras del tradicionalismo- son saltos y nombres heterogéneos que provienen de la intelectualidad liberal antes de adoptar una significación tradicionalista ${ }^{84}$. Pero la tesis de la dos Españas ya había adoptado la imagen de una polarización de la sociedad en dos bloques irreconciliables, pronto interpretada como el fruto castizo de nuestro cainismo.

Azaña intentó superar esa visión de las dos Españas. Si la Restauración canovista se presentó como la continuación de la historia de España, la República azañista lo hizo como una rectificación de la historia de España. La cualidad de español y de nacionalidad española no podía depender de un régimen político ni de la estructura del Estado (no era consustancial al principio monárquico). El

79 BOYD, 1997, pp. 165-193. OUIMETTE, V.: Los intelectuales españoles y el naufragio del liberalismo, 1923-1936, Valencia, Pre-Textos, 1998.

${ }^{80}$ Faus Sevilla, P. La sociedad española del siglo XIX en la obra de Pérez Galdós, Valencia, 1972.

81 Fernández Urbina, J.M.: La aventura intelectual de Ramiro de Maeztu, Vitoria, Diputación Foral de Alava, 1998. Villacañas, J.L.: Ramiro de Maeztu y el ideal de la burguesía en España, Madrid, Espasa Calpe, 2000.

82 GonZÁlez CuEvas, P.C.: La tradición bloqueada: tres ideas políticas en España: el primer Ramiro de Maeztu, Charles Maurras y Carl Schmitt, Madrid, Biblioteca Nueva, 2002; Acción española. Teología política y nacionalismo autoritario en España (1913-1936), Madrid, Tecnos, 1998. SUTTON, M.: Nationalism, Positivismn and Catbolicism: The Politics of Charles Maurras and French Catbolics, 1890-1914. Nueva York, Cambridge University. Press, 1982. GoYeT, B.: Charles Maurras, París, Presses de Sciences Politiques, 2000.

${ }_{83}$ Maeztu, R. de: Defensa de la Hispanidad. Introducción de Federico Suárez, Madrid, Rialp, 1998.

${ }^{84} \mathrm{La}$ idea se encuentra perfilada por Vicente $\mathrm{CACHO}$ VIU en una carta que reproduce Octavio RUIZ-MANJón en la introducción al libro póstumo de Cacho, Los intelectuales y la política, pp. 42-44. 
fracaso histórico del Estado centralista, de la opción jacobina de un Estado nacional unitarista — que tuvo su gran oportunidad en España con la guerra de la independencia, considera Azaña-, llevaba a poner la mirada en los verdaderos orígenes del Estado, lo que Azaña llamaba «el gran Estado español del Renacimiento" a comienzos del siglo XVI (la Monarquía plural de los Austrias), que no fue asimilista, aunque sí despótica, lo que propició - añadía - la aparición de «una gran tradición liberal, de una gran tradición popular». En ese sentido, no tenía reparos en declararse tradicionalista y en formular un claro criterio para la solución de los problemas políticos y de la misma cuestión nacional: «la tradición corregida por la razón» ${ }^{85}$.

La nueva España de la generación del 14, el proyecto de una España plural, será retomado por la generación de 1978 tras la muerte de Franco

\section{LA DEFORMACIÓN DE LA CONCIENCIA HISTÓRICA}

Junto a la hipercrítica del 98 y la transmutación del mito de las dos Españas, se pueden señalar otros factores que han contribuido en los tiempos recientes a la deformación de la conciencia histórica y de la imagen de España, consiguiendo articular el mito del fracaso. En concreto: el tradicionalismo, el materialismo histórico y los nacionalismos.

\section{La España eterna y el fracaso de España}

El reduccionismo religioso y la instrumentación política de la religión operados durante el régimen franquista cimentan una España eterna indistinta de la historia sagrada. La historia de España comienza en el paraíso terrenal, con la expulsión de Adán y Eva, y acaba con Franco, guía y salvador. Es un esquema que se mantiene en los manuales escolares durante mucho tiempo ${ }^{86}$. Asistimos a la anulación del tiempo histórico y de la propia conciencia del sujeto. De la intrahistoria se llega a la España eterna. La hipercrítica anticanovista y los excesos literarios de fin de siglo habían hecho, en último término, el trabajo grueso al franquismo. La desaparición previa del XIX simplifica el entronque

85 AZAÑA, M.: Discurso de clausura de la reunión de Acción Republicana, 28 de marzo de 1932 («La República como forma del ser nacional»), en Obras Completas, II, pp. 227-228. Discurso en Valencia, 4 de abril de 1932 («La República como pensamiento y acción»), en OC, II, pp. 241-242. Discurso en las Cortes, 27 de mayo de 1932 («El Estatuto de Cataluña»), en OC, II, pp. 259-265.

${ }^{86}$ LINACERO, D.G.: Enseñar bistoria con una guerra civil por medio, introducción de J. FONTANA, Barcelona, Crítica, 1999. VALLS MONTES, R.: La interpretación de la Historia de España y sus orígenes ideológicos en el bacbillerato franquista (1938-1953), Valencia, ICE, 1984. LÓPEZ MARCOS, M.: El fenómeno ideológico del franquismo en los manuales escolares de enseñanza primaria (1936-1945), Madrid, UNED, 2001.

Hispania, LXV/1, núm. 219 (2005) 281-306 
con el Siglo de Oro y los valores del Imperio como sustrato ideológico del régimen y como superación de la falla histórica. En las polémicas del régimen (Laín-Calvo Serer, 1949) Menéndez Pelayo y Maeztu serán canonizados frente a cualquier reivindicación ambigua de la herencia de Ortega ${ }^{87}$.

La propia realidad de la dictadura franquista insta en el exilio a los discípulos de Hinojosa y Menéndez Pidal a la búsqueda de las causas de la inadaptación de España a la modernidad. La existencia de un carácter nacional (la idea que introdujo Masdeu dos siglos antes) como causa del aislamiento español determinará la gran polémica de la historia de la historiografía española, la polémica Castro-Sánchez Albornoz $(1948,1954)$, rebosante de preocupación metafísica por el ser de España ${ }^{88}$. Frente a la tesis de Castro que concebía a España como el fruto de la convivencia de cristianos, musulmanes y judíos, cifrando en la expulsión de estos últimos el origen de la parálisis española, Sánchez Albornoz estima que el carácter propio de España aparece ya definido en la España primitiva prerromana. Los visigodos, al introducir usos y formas de vida germánicos, enriquecieron el ser hispánico, pero sin alterar su esencia. Con Sánchez Albornoz, presidente de la República en el exilio, regresan los iberos, aunque su visión logre, en el fondo, hacer confluir la doble raíz doctrinaria y republicana de la historiografía del XIX. Por otra parte, como había hecho Menéndez Pidal, confiere a Castilla un protagonismo esencial en la formación de la peculiaridad del ser español.

Vicens Vives será el principal agente de la superación del tradicionalismo y del debate metafísico sobre España así como de su imagen castellana ${ }^{89}$. Introductor en España de la nouvelle bistoire de Annales, realiza una lectura particular de la polémica entre Castro y Sánchez-Albornoz para extraer dos conclusiones: la «imperfección de España» para seguir el rumbo de la civilización occidental hacia el capitalismo y el «fracaso de la misión de Castilla en la tarea de hacer a España». Pese a su novedad, la historia de España con Vicens seguía siendo la historia de una frustración, por más que rechazase la «angustia unamuniana» de aquellos historiadores ${ }^{90}$. La necesidad de romper con el idealismo y el afán de materializar la historia se acompaña de la propuesta de «regionalizar» la his-

87 PASAMAR, G.: Historiografía e ideología en la postguerra española: la ruptura de la tradición liberal, Zaragoza, Universidad de Zaragoza, 1991. FERRARY, A.: El franquismo: minorías políticas y conflictos ideológicos, 1936-1956, Pamplona, Eunsa, 1993.

88 ARAYA, G.: El pensamiento de Américo Castro. Estructura intercastiza de la historia de España, Madrid, Alianza, 1983. Almeida, J.: El problema de España en la obra de Américo Castro, Cordoba, Universidad de Córdoba, 1993. MarTín, J.L.: Claudio Sáncbez-Albornoz, Valladolid: Junta de Castilla y León., 1986. CABEza SÁNCHEZ-AlBORNOZ, S.: Semblanza bistórico-política de Claudio Sánchez Albornoz, Madrid, Fundación Universitaria Española, 1993.

${ }^{89}$ MUÑOZ I LLORET, J.M.: Jaume Vicens Vives. Una biografia. Intel.lectual, Barcelona, Edicions 62, 1997. De RiQuer, B.: "Jaume Vicens i Vives: renovación metodológica y responsabilidad social», en Revista de Occidente (Madrid), 152 (1994), pp. 141-155.

90 DARDÉ, C.: La idea de España en la bistoriografía del siglo XX, Santander, Servicio de Publicaciones, Universidad de Cantabria, 1999, pp. 25-27. 
toria de España contra la reductora visión de la «escuela erudita y filológica nacionalista castellana» (Menéndez Pidal y discípulos).

Vicens Vives se había enfrentado asimismo al nacionalismo historiográfico catalán polemizando con Rovira i Virgili91 en los años 30, momento en que se concretó la gran imagen de la historia nacional catalana de Ferrán Soldevila, la figura principal dentro de la historiografía del noucentisme catalán ${ }^{92}$. Las tesis de Vivens Vives proporcionarán un nuevo marco interpretativo donde los orígenes mismos del nacionalismo catalán se explican como el resultado de la frustración de la burguesía catalana industrial en el marco de una España esencialmente agraria y con un sentido castellanista del Estado, interpretación que introducía nuevos elementos susceptibles de crítica.

En cualquier caso, la vuelta generalizada al pasado en los tiempos de la dictadura y la idea del fracaso de España facilitaron el análisis marxista posterior.

\section{El bloque de poder}

Junto a las aportaciones de Vivens Vives, las nuevas tendencias historiográficas de los años 60 y 70, marcadas por el peso de la historia social y económica, llegan a España a través del marxismo. Las obras de Pierre Vilar y de Tuñón de Lara resultan en ese sentido fundamentales, y constituyen además un decidido esfuerzo por recuperar y racionalizar el pasado español frente a las mixtificaciones del franquismo. Esa labor, impulsada igualmente a través de los coloquios organizados por Tuñón a partir de 1970, primero en Pau y en los últimos tiempos en el País Vasco, abrió nuevos cauces de investigación, por más que al final haya evidenciado sus propios límites.

La Catalagne dans l'Espagne moderne (1962) de Vilar vuelve sobre la interpretación de Vicens profundizando en los orígenes del capitalismo en Cataluña y los fundamentos últimos de la peculiaridad industrial catalana en el conjunto español. Su impronta en diferentes sectores catalanistas perdura hasta hoy, aunque ese modelo de análisis se resienta - como ha resaltado Fradera- por la escasa atención que presta a las motivaciones de los agentes sociales protagonistas de la historia real ${ }^{33}$.

\footnotetext{
91 Bladé I Desumvila, A.: Antoni Rovira i Virgili i el seu temps, Barcelona, Rafael Dalmau, 1984. SOBREQUÉS I CALLICó, J.: Antoni Rovira i Virgili: bistòria i pensament polític, Barcelona, Curial, 2002.

92 AUReLl, J.: «Historiografía y nacionalismo en la Cataluña contemporánea, 1830-1960», en AlvareZ, A. y otros (coords.): El siglo XX: balance y perspectivas, Valencia, Cañada Blanch, 2000, pp. 11-14. Fontana, J. I L. DuRAn (eds.) Per conèixer Ferran Soldevila, Barcelona, Publicacions de l'Abadia de Montserrat, 1994. MONTORIOL I SABATÉ, R.: Ferran Soldevilla (1894-1971): una aproximació bibliográfica, Barcelona, Afers, 1994. PujOL CASADEMONT, E.: Ferran Soldevila i els fondaments de la bistoriografia catalana contemporània, tesis doctoral leída en la Universidad Autónoma de Barcelona, 1994.

93 Fradera, 1999, p. 89. VILAR, P.: Pensar históricamente: reflexiones y recuerdos, edición preparada y anotada por R. CONGOST, Barcelona, Grijalbo Mondadori, 1997.
}

Hispania, LXV/1, núm. 219 (2005) 281-306 
Es lo que sucede con el concepto de bloque de poder formulado por Tuñón de Lara ${ }^{94}$, aplicando al análisis histórico español el interés por los modelos y las estructuras de la historiografía francesa del momento con algún añadido marxista. Grupo abstracto elevado a la categoría de sujeto, el bloque de poder aparece como un frente único formado por los grandes terratenientes y financieros, que se configuró a principios del XIX, logró adaptarse totalmente al sistema liberal y se convirtió en auténtica fuente de poder y control político, con fuerza suficiente para doblegar partidos y parlamentos y obtener de gobiernos de distinto signo disposiciones favorables para la consolidación de su propio dominio económico y social, impidiendo la presencia y participación política de las clases medias y populares. Particularmente responsable del fiasco del sistema político de la Restauración, el concepto se vuelve sumamente operativo en la explicación del fracaso en España de la revolución burguesa y de la industrialización, de las dos repúblicas, y en suma de las reformas políticas, sociales y económicas imprescindibles para construir una sociedad moderna y justa.

Aunque por encima de los métodos, las modas y los modelos (aun los globales de la tradición marxista), la obra historiográfica de Tuñón prime la búsqueda de lo específico - el establecimiento de las peculiaridades de cada «formación económico-social», según valora Pérez Ledesma ${ }^{95}$, la teoría del bloque de poder oligárquico (cuya defunción como mito historiográfico fue certificada a finales de los ochenta ${ }^{96}$ ) no es, en el fondo, más que una redefinición en clave marxista del análisis de Costa.

Su influencia se ha hecho notar en la nueva historiografía vasca desarrollada a partir de los años $70^{97}$, especialmente crítica respecto al nacionalismo, al contrario que en Cataluña, pero no menos responsable también, buscando el reverso del caso catalán, de una cierta deformación en la explicación de la génesis histórica del nacionalismo vasco ${ }^{98}$.

94 TUÑÓN DE LARA, M.: Historia y realidad del poder: el poder y las élites en la España del primer tercio del siglo XX, Madrid, Cuadernos para el Diálogo, 1967. «La burguesía y la formación del bloque de poder oligárquico", en su Estudios sobre el siglo XIX español, Madrid, Siglo XXI, 1972, pp. 155-238.

95 Pérez Ledesma, M.: «La memoria y el olvido: Manuel Tuñón de Lara y la historiografía española», en GRANJA, J.L y otros: Tuñón de Lara y la bistoriografía española, Madrid, Siglo XXI, 1999, pp. 21-36. Véase también HeRNÁNDEZ SANDOICA, E. «Sobre historiografía española: Manuel Tuñón de Lara y la pasión del método», en Hispania (Madrid), 188 (1994), pp. 1145-1153.

96 MARTÍn ACEÑA, P.: «Réquiem por el bloque de poder», en Revista de Occidente (Madrid), 113 (1990), pp. 151-154.

97 GRANJA, J.L.: «La nueva historiografía vasca», en Tuñon de Lara y la bistoriografía española, pp. 287-304.

98 SÁNCHEZ-PrieTO, J.M.: «Problemas de historiografía vasca contemporánea», en II Congreso Mundial Vasco. Congreso de Historia de Euskal Herria, San Sebastián, Txertoa, 1988, tomo V, pp. 413 431. Aizpuru, M.: «La pluralidad de vías en la reformulación de la identidad vasca en el siglo XIX», Sancho el Sabio. Revista de cultura e investigación vasca (Vitoria), 15 (2001), pp. 11-44. 


\section{El finalismo nacionalista}

Finalmente, los distintos nacionalismos son responsables también de una deformación de la conciencia histórica. El finalismo de cualquier historiografía nacionalista no ve en la evolución del proceso político y cultural de la propia comunidad sino antecedentes del nacionalismo. El nacionalismo, de un signo u otro, ha asaltado de forma permanente la conciencia histórica de la España contemporánea.

Durante la Transición democrática, sin embargo, el efecto de la efervescencia nacionalista fue mayor por la misma pérdida de memoria histórica producida bajo la dictadura. La proliferación de historias nacionalistas incluso en comunidades donde en el mejor de los casos históricamente sólo había existido regionalismo ha impedido o dificultado la recuperación no ya de la memoria histórica de la nación española sino de la misma historia de España ${ }^{99}$. Del mito del carácter nacional (puesto en evidencia por Caro Baroja ${ }^{100}$ ) y de la España eterna franquista se pasa sin solución de continuidad a la negación de España, reducida al Estado español, y a la invención de nuevos mitos, béroes y símbolos nacionales. Precedido de otras iniciativas ${ }^{101}$, el informe publicado por la Real Academia de la Historia en el año 2000 - aun resucitando la vieja imagen de Godoy de la institución al servicio del poder (y algunas preocupaciones metafísicas) - apuntó los efectos de esa realidad en la convivencia colectiva.

\section{LA REINVENCIÓN DE LA NACIÓN}

Con todo, la voluntad política de construir una nueva España durante la Transición, la España de las Autonomías, que recogía la herencia de Ortega y Azaña, ha venido acompañada de una nueva historiografía sobre la nación. La crisis de los paradigmas científicos dominantes en las décadas anteriores ha favorecido no sólo el retorno sino la reinvención de la nación ${ }^{102}$.

La imagen de una España normal (con tendencia a la pasividad y a remolque si se quiere de la evolución europea, pero plenamente inscrita en ella ${ }^{103}$ ) se

99 Pérez Garzón, S. y otros: La gestión de la memoria. La historia de España al servicio del poder, Barcelona, Crítica, 2000 (LÓPEZ FACAL, R. «La nación ocultada», pp. 111-159; Rivière GóMEZ, A.: «Envejecimiento del presente y dramatización del pasado. Una aproximación a las síntesis históricas de las Comunidades Autónomas españolas, 1975-1995», pp. 161-219).

${ }^{100}$ CARO BAROJA, J.: El mito del carácter nacional. Meditaciones a contrapelo, Madrid, Seminarios y Ediciones, 1970.

101 Real ACADemia de la Historia, España. Reflexiones sobre el ser de España, Madrid, 1997; España como nación, Barcelona, Planeta, 2000.

102 TUSELL, J.: «El retorno de la nación», en su España, una angustia nacional, Madrid, Espasa Calpe, 1999, pp. 19-52. BAAMONDE, A.: La reinvención de España: una radiografía de la España de boy, Barcelona, Ronsel, 2001.

103 ANDRÉs-Gallego, J.: «El problema (y la posibilidad) de entender la historia de España», en Historia de la bistoriografía española, Madrid, Ediciones Encuentro, 1999, pp. 323-324. 
ha abierto paso. A la negación o superación de la idea de excepcionalidad española y del mito del fracaso han contribuido de forma fundamental los trabajos de Raymond Carr y de sus discípulos. Para Carr el fracaso fundamental de la España contemporánea fue un fracaso político; y se podría aún añadir: un fracaso del Estado centralista. Las tesis del fracaso de la revolución industrial y de la revolución burguesa en España revisten hoy el carácter de mito y no cabe hablar en el plano socioeconómico más que de atraso relativo. En el campo de la historiografía política - como ha subrayado Dardé- los nuevos trabajos sobre el caciquismo han dejado reducido la fantástica oligarquía a una clase política de jóvenes ambiciosos que encontró en el servicio del Estado la principal vía de movilidad social, fundamentando la base de su influencia política en los favores personales y el clientelismo, al igual que sucede en otros países europeos en un contexto de desmovilización política ${ }^{104}$.

- La tesis de la normalidad encuentra, no obstante, diferentes obstáculos, fundamentalmente en el enfoque de la cuestión nacional. Es ese posiblemente el mayor reto historiográfico actual. La interpretación de la historia no puede quedar atrapada en un conflicto de nacionalismos - han pasado los tiempos del historiador nacionalista-, pero la función social de la historia tampoco puede desvincularse de la cuestión de la identidad. No basta con proclamar la virtualidad de las identidades múltiples. Los conceptos de España como nación de naciones o Estado plurinacional, entre otros, lejos de ser evidentes, presentan significados y problemas de interpretación histórica distintos ${ }^{105}$. Aun en manos de historiadores, manifiestan mucho más una voluntad de orientar políticamente un problema que la realidad de una elaboración historiográfica consistente detrás. En cualquier caso, la comprensión actual de España como una nación plural no responde seguramente a la presunta debilidad del proceso de nacionalización española en el siglo XIX (Borja de Riquer), ni a la inexistencia de un nacionalismo español durante ese período y aún después (Fusi), ni se explica como un simple giro frente al españolismo reactivo progresivamente afirmado desde el último cuarto del XIX (Álvarez Junco) ${ }^{106}$. Tampoco la renovación democrática de la idea de España es suficiente para ensalzar el nacionalismo cívico frente al nacionalismo étnico, en un ejercicio voluntarista de nuevo nacionalismo español (Uriarte) ${ }^{107}$.

104 DARDÉ, 1999, p. 33.

10s SÁNCHEZ-Prieto, J.M.: La España plural. El debate de la identidad, Bilbao, Elkargunea, 1999.

${ }^{106}$ DE RiQUer, B.: «Nacionalidades y regiones. Problemas y líneas de investigación en torno a la débil nacionalización española del siglo XIX», en MORALES MOYA, A. y M. ESTEBAN DE VEGA (ed.): La Historia Contemporánea en España, Salamanca: Universidad de Salamanca, 1996, pp. 73-89 (una nueva versión en su Identitats contemporànies, pp. 21-43). FUSI, J.P.: España. La evolución de la identidad nacional, Madrid, Temas de Hoy, 2000, pp. 163-165. Álvarez JUNCO.: «Un españolismo reactivo", en su Mater Dolorosa, pp. 601-607.

107 URIARTE, E.: España, patriotismo y nación, Madrid, Espasa Calpe, 2003. 
La reinvención de la nación — su nuevo asentamiento en el presente prescindiendo de cualquier concepto excluyente de soberanía - pasa por la depuración de la memoria histórica en torno al mismo proceso de construcción nacional, tanto desde una perspectiva española como catalana o vasca, así como de los respectivos discursos de legitimación o críticos vertidos a lo largo del tiempo, valorando mucho más los distintos proyectos de inclusión formulados desde el reconocimiento conjunto de las diferencias y de las lealtades compartidas, que la dialéctica de mutuas exclusiones por decisiva que ésta resulte en determinados momentos. No se puede obviar, en definitiva, que las fuentes intelectuales que alimentan la conciencia nacional y que fundamentan el propio discurso histórico sobre la nación, no son específicas, participan de la atmósfera europea, y son a fin de cuentas muchas veces las mismas. Más allá de las imágenes fabricadas y del antagonismo resultante en el cruce de miradas, identidades desenvueltas en la misma estratosfera cultural están más próximas de compartir proyectos comunes. Ser conscientes de ello puede ayudar a superar lo que Jover (referido a las dos Españas, pero puede hacerse extensivo a toda la cuestión nacional) llamó un día el siniestro estrabismo. 